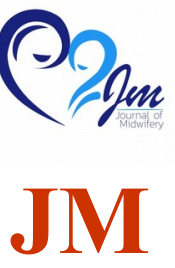

Volume 8 No. 1 (April 2020)

(C) The Author(s) 2020

\title{
HUBUNGAN PENGETAHUAN DAN MOTIVASI IBU DENGAN PEMBERIAN KOMPRES HANGAT PADA BALITA FEBRIS DI BPM YETTI PURNAMA, S.ST., M.KEB KOTA BENGKULU
}

\section{THE RELATIONSHIP OF KNOWLEDGE AND MOTIVATION OF MOTHER WITH THE PROVISION OF WARM COMPRESSES IN FEBRIS TODDLERS IN BPM YETTI PURNAMA, S.ST., M.KEB BENGKULU CITY}

\author{
RONALEN BR. SITUMORANG, DESI AULIA UMAMI, MITRA KADARSIH \\ PROGRAM STUDI KEBIDANAN (DIII) \\ FAKULTAS ILMU KESEHATAN \\ UNIVERSITAS DEHASEN BENGKULU \\ Email: ronalen@gmail.com, desiumami@gmail.com
}

\begin{abstract}
ABSTRAK
Rendahnya kesehatan orang tua, terutama ibu dan anak bukan hanya karena sosial ekonominya yang rendah, tetapi sering juga disebabkan karena orang tua, atau ibu tidak mengetahui bagaimana cara memelihara kesehatannya dan kesehatan anaknya, misalnya saat balita demam ibu tidak melakukan kompres hangat pada balitanya. Surveilans Departemen Kesehatan RI, frekuensi kejadian demam di frekuensi menjadi 15,4 per 10.000 penduduk. Dari survey berbagai rumah sakit di Indonesia dari tahun 1981 sampai dengan 1986 memperlihatkan peningkatan jumlah penderita sekitar $35,8 \%$. Tujuan penelitian mengetahui hubungan pengetahuan dan motivasi ibu dengan pemberian kompres hangat pada balita febris di bpm yetti purnama, s.st., m.keb Kota Bengkulu. Metode penelitian ini jenis penelitian Kuantitatif Non Eksperimental dengan menggunakan pendekatan studi korelasi (cross sectional). Sampel pada penelitian ini diambil secara accidental sampling pada bulan Februari tahun 2019 yang berjumlah 35 Balita. Hasil penelitian penulis Terdapat hubungan yang signifikan antara pengetahuan ibu dengan pemberian kompres hangat. Dimana nilai P-value $0.01<0.05$. Terdapat hubungan yang signifikan antara Motivasi ibu dengan pemberian kompres hangat. Dimana nilai P-value $0.028<0.05$.Saran, perlu dilakukan upaya peningkatan sosialisasi dan cara penyampaian informasi yang efektif dan berkesinambungan oleh petugas puskesmas.
\end{abstract}

Kata Kunci: Pengetahuan, Motivasi dan Kompres Hangat

\section{ABSTRACT}

The low health of parents, especially mothers and children, is not only due to their low socioeconomic status, but is often also caused by parents, or mothers not knowing how to take care of their health and the health of their children, for example when toddlers have a fever the 
mother does not warmly compress the toddler. Surveillance of the Ministry of Health of the Republic of Indonesia, the frequency of fever occurrences in frequency to 15.4 per 10,000 population. From a survey of various hospitals in Indonesia from 1981 to 1986 showed an increase in the number of patients around $35.8 \%$. The purpose of this study was to determine the relationship of mother's knowledge and motivation with the provision of warm compresses to febrile toddlers at BPM Yetti Purnama, S.ST, M.Keb Bengkulu City. This research method is Non-Experimental Quantitative research using a correlation study (cross sectional) approach. The sample in this study was taken by accidental sampling in February 2019, amounting to 35 toddlers. The results of the author's research There is a significant relationship between mother's knowledge with the provision of warm compresses. Where the value of P-value $0.01<0.05$. There is a significant relationship between maternal motivation with warm compresses. Where the $\mathrm{P}$-value is $0.028<0.05$. Suggestions, it is necessary to make efforts to increase socialization and how to deliver effective and continuous information by puskesmas staff.

\section{Keywords: Knowledge, Motivation and Warm Compress}

\section{PENDAHULUAN}

Rendahnya kesehatan orang tua, terutama ibu dan anak bukan hanya karena sosial ekonominya yang rendah, tetapi sering juga disebabkan karena orang tua, atau ibu tidak mengetahui bagaimana cara memelihara kesehatannya dan kesehatan anaknya, misalnya saat balita demam ibu tidak melakukan kompres hangat pada balitanya (Notoatmodjo, 2010).Di keluarga, orang tua sangatlah dicintai dan dibanggakan oleh anak, begitu juga sebaliknya anak merupakan buah hati yang sangat berharga, yang harus dijaga dan dilindungi, sehingga saat anak sakit timbul suatu kekhawatiran seketika yang menimbulkan reaksi emosi serta terjadi ekspresi tingkah laku yang tidak biasa. Orang tua, khususnya ibu adalah faktor yang sangat penting dalam mewariskan status kesehatan kepada anak-anak mereka.

World Health Organization(WHO) mengemukakan jumlah kasus demam di seluruh dunia mencapai 18-34 juta, Anak merupakan yang paling rentan terkena demam, walaupun gejala yang dialami anak lebih ringan dari dewasa. Di hampir semua daerah endemik, insidensi demam banyak terjadi pada anak usia 1-19 tahun (Niken J,2011).

Di Indonesia penderita demam sebanyak $465(91.0 \%)$ dari 511 ibu yang memakai perabaan untuk menilai demam pada anak mereka sedangkan sisanya 23,1 saja menggunakan thermometer (Setyowati, 2013). Pengetahuan dipengaruhi pendidikan oleh faktor pendidikan formal. Pengetahuan sangat erat hubungannya dengan pendidikan, dimana dengan pendidikan tinggi maka akan semakin luas pula pengetahuannya. Akan tetapi bukan berarti seseorang yang berpendidikan rendah mutlak berpengetahuan rendah pula. Pengetahuan yang dicari seseorang memiliki pengaruh pada peningkatan kemampuan berpikir dengan kata lain seseorang yang berpengetahuan tinggi akan dapat mengambil keputusan yang lebih baik umumnya terbuka untuk menerima perubahan atau hal baru dibandingkan dengan yang berpengetahuan lebih rendah, begitu pula halnya dengan pengetahuan ibu dalam merawat balitanya yang sedang mengalami febris (Wawan dan Dewi, 2011).

Motivasi adalah suatu perubahan tenaga didalam diri seseorang yang ditandai oleh mengakibatkan seseorang mau dan rela untuk mengerahkan kemampuan dalam bentuk keahlian atau keterampilan tenaga dan waktunya untuk menyelenggarakan berbagai kegiatan yang menjadi tanggung jawabnya dan menuaikan kewajibanya dalam rangka pencapaian tujuan dari berbagai sasaran yang telah ditentukan sebelumnya begitu pula halnya dengan ibu dalam mengatasi demam pada anaknya (Soemanto, 2009).

Penanganan terhadap demam dapat 
dilakukan dengan tindakan farmakologis, tindakan non farmakologis maupun kombinasi keduanya .Tindakan farmakologis yaitu memberikan obat antipiretik.Sedangkan tindakan non farmakologis yaitu tindakan tambahan dalam menurunkan panas setelah pemberian obat antipiretik.Tindakan non farmakologis terhadap penurunan panas seperti memberikan minuman yang banyak, ditempatkan dalam ruangan bersuhu normal, menggunakan pakaian yang tidak tebal, dan memberikan kompres (Kania, 2007).

Kompres hangat adalah tindakan denganmenggunakan kain atau handuk yang telah dicelupkan pada air hangat, yang ditempelkan pada bagian tubuh tertentu sehingga dapat memberikan rasa nyaman dan menurunkan suhu tubuh (Maharani, 2011). Berdasarkan survey awal dari 7 orang ibu yang membawa anaknya demam berobat ke BPM Bidan Yetti Purnama, SST., M.Keb, diketahui 4 orang ibu beranggapan demam merupakan suatu penyakit yang perlu segera diobati dan tidak melakukan kompres hangat pada anaknya karena kompres hangat merupakan cara yang kurang efektif untuk menurunkan panas pada anak, dan 2 orang ibu beranggapan demam merupakan gejala suatu penyakit yang bisa dibantu dengan kompres hangat untuk menurun panas selain obat.

Berdasarkan latar belakang di atas maka peneliti tertarik untuk melakukan penelitian tentang "Hubungan Pengetahuan dan Motivasi Ibu dengan Pemberian Kompres Hangat pada Balita Febris di BPM Bidan Yetti Purnam, SST., M.Keb Kota Bengkulu Tahun 2019".

Tujuan dari penelitian ini adalah hubungan pengetahuan dan motivasi ibu dengan pemberian kompres hangat pada balita febris di BPM Bidan Yetti Purnam, SST., M.Keb Kota Bengkulu Tahun 2019”.

\section{METODE PENELITIAN}

Penelitian ini menggunakan metode deskriptif dengan rancangan cross sectional. Alasan pemilihan deskriptif, karena penelitian ini bertujuan untuk untuk pengetahuan dan motivasi ibu dengan pemberian kompres hangat pada balita febris. Populasi adalah keseluruhan subjek penelitian yang akan diteliti (Notoatmodjo, 2010). Populasi dalam penelitian ini adalah seluruh ibu yang mempunyai balita di BPM Yetti Purnama, SST., M.Keb kota Bengkulu sebanyak 35 orang

Sampel adalah sebagian dari keseluruhan objek yang diteliti dan dianggap mewakili seluruh populasi (Notoatmodjo, 2010). Informan yang digunakan dalam penelitian ini adalah 35 orang di BPM Bidan Yetti Purnama, SST., M.Keb kota Bengkulu. Teknik pengambilan informan dalam penelitian ini adalah dengan menggunakan teknik accidental sampling yaitu teknik yang dilakukan dengan mengambil kasus atau responden yang kebetulan ada atau tersedia di suatu tempat sesuai dengan konteks penelitian (Notoatmodjo, 2012).

Teknik pengumpulan data yang digunanakan dalam penelitian ini adalah dengan menggunakan data primer dan data sekunder.Data primer yaitu data yang akan diambil dengan cara memberikan kuesioner langsung dengan ibu balita. Data sekunder yaitu data yang diperoleh dari profil Dinkes Kota dan BPM Bidan Yetti Purnama, SST., M.Keb Kota Bengkulu

Pada penelitian ini peneliti memeriksa satu per satu data yang telah di entry mengubah setiap kekeliruan atau kesalahan yang terjadi pada saat melakukan entry data. Data bersih merupakan Setelah semua kuisioner terisi penuh dan benar, serta sudah melewati pengkodean, maka selanjutnya adalah memproses data agar data yang sudah di-entry data dan koesioner ke paket program komputer.

Dalam penelitian kesehatan uji signifikan dilakukan dengan menggunakan batas kemaknaan (alpha) $=0,05$ dan 95\% confidence interval. Dengan ketentuan bila: $\mathrm{P}$ value $\leq$ 0,05 berarti Ho ditolak $(\mathrm{P}$ value $\leq \alpha)$. Uji statistik menunjukkan adanya hubungan yang signifikan. $\mathrm{P}$ value $>0,05$ berarti Ho gagal ditolak (P value $>\alpha)$. Uji statitik 
menunjukkan tidak ada hubungan yang signifikan.

Uji Chi Square digunakan karena variabel dependen dan independen dalam penelitian ini bersifat katagorik. penelitian ini menggunakan batas bermakna secara statistik sebesar 5\%, sehingga jika diperoleh nilai p>alpha, maka hasil perhitungan statistiknya tidak bermakna, artinya tidak ada hubungan signifikan antara variabel dependen dengan variabel independen. sebaliknya jika diperoleh nilai $\mathrm{p} \leq$ alpha, maka hasil perhitungan statistiknya bermakna, artinya ada hubungan yang signifikan antara variabel dependen dengan variabel independen.

Pengumpulan data dalam bentuk tertulis mulai dari pengambilan sampel, pelaksanaan pengumpulan data dan sampai hasil analisis yang berupa informasi dari pengumpulan data tersebut dan penyajian data secara tabular yaitu memberikan keterangan berbentuk angka. Jenis yang digunakan dalam penelitian ini adalah master tabel dan tabel distribusi frekuensi. Dimana data disusun dalam baris dan kolom dengan sedemikian rupa sehingga dapat memberikan gambaran.

\section{HASIL PENELITIAN}

a. Umur Ibu

Jumlah responden sebanyak 35, sebaran umur ibu yang paling muda adalah 24 tahun dan yang paling tua adalah 35 tahun. Ratarata umur ibu yaitu 28 tahun.Standar deviasi berfungsi untuk melihat sebaran data dalam sampel.Semakin rendah nilai standar deviasi maka semakin kecil tingkat variasi nilai umur ibu.

Tabel 1. Distribusi Frekuensi Analisis Univariat

\begin{tabular}{|c|c|c|c|c|}
\hline \multicolumn{5}{|c|}{ Umur Ibu } \\
\hline & Frequency & Percent & $\begin{array}{c}\text { Valid } \\
\text { Percent }\end{array}$ & $\begin{array}{c}\text { Cumulative } \\
\text { Percent }\end{array}$ \\
\hline $\begin{array}{c}\text { Valid } 24.0 \\
0 \\
\end{array}$ & 5 & 14.3 & 14.3 & 14.3 \\
\hline $\begin{array}{c}25.0 \\
0 \\
\end{array}$ & 12 & 34.3 & 34.3 & 48.6 \\
\hline $\begin{array}{c}26.0 \\
0 \\
\end{array}$ & 2 & 5.7 & 5.7 & 54.3 \\
\hline $\begin{array}{c}28.0 \\
0 \\
\end{array}$ & 2 & 5.7 & 5.7 & 60.0 \\
\hline $\begin{array}{c}29.0 \\
0 \\
\end{array}$ & 1 & 2.9 & 2.9 & 62.9 \\
\hline $\begin{array}{c}30.0 \\
0 \\
\end{array}$ & 2 & 5.7 & 5.7 & 68.6 \\
\hline $\begin{array}{c}31.0 \\
0 \\
\end{array}$ & 3 & 8.6 & 8.6 & 77.1 \\
\hline $\begin{array}{c}32.0 \\
0 \\
\end{array}$ & 3 & 8.6 & 8.6 & 85.7 \\
\hline $\begin{array}{c}34.0 \\
0 \\
\end{array}$ & 1 & 2.9 & 2.9 & 88.6 \\
\hline $\begin{array}{c}35.0 \\
0 \\
\end{array}$ & 4 & 11.4 & 11.4 & 100.0 \\
\hline Total & 35 & 100.0 & 100.0 & \\
\hline
\end{tabular}

Jika dilihat menurut usia dari 35 responden ibu, jumlah terbanyak pada umur 25 tahun dengan persentase $34.3 \%(n=12)$ dan jumlah terendah pada usia 34 tahun dengan persentase $2.9 \%(n=1)$.

\section{b. Umur Balita}

Jumlah responden sebanyak 35, sebaran umur balita yang paling muda adalah 1.1 tahun dan yang paling tua adalah 5 tahun. Rata-rata umur balita yaitu 3 tahun. 


\begin{tabular}{|c|c|c|c|c|}
\hline \multicolumn{5}{|c|}{ Umur Balita } \\
\hline & Frequency & Percent & $\begin{array}{c}\text { Valid } \\
\text { Percent }\end{array}$ & $\begin{array}{c}\text { Cumulative } \\
\text { Percent }\end{array}$ \\
\hline Valid 1.10 & 1 & 2.9 & 2.9 & 2.9 \\
\hline 1.13 & 1 & 2.9 & 2.9 & 5.7 \\
\hline 1.15 & 2 & 5.7 & 5.7 & 11.4 \\
\hline 1.20 & 1 & 2.9 & 2.9 & 14.3 \\
\hline 2.00 & 6 & 17.1 & 17.1 & 31.4 \\
\hline 2.10 & 1 & 2.9 & 2.9 & 34.3 \\
\hline 2.11 & 1 & 2.9 & 2.9 & 37.1 \\
\hline 2.50 & 1 & 2.9 & 2.9 & 40.0 \\
\hline 2.80 & 2 & 5.7 & 5.7 & 45.7 \\
\hline 2.90 & 1 & 2.9 & 2.9 & 48.6 \\
\hline 3.00 & 4 & 11.4 & 11.4 & 60.0 \\
\hline 3.10 & 2 & 5.7 & 5.7 & 65.7 \\
\hline 4.00 & 6 & 17.1 & 17.1 & 82.9 \\
\hline 5.00 & 6 & 17.1 & 17.1 & 100.0 \\
\hline Total & 35 & 100.0 & 100.0 & \\
\hline
\end{tabular}

Jika dilihat menurut usia dari 35 responden balita, jumlah terbanyak pada umur 2, 4, dan 5 tahun dengan persentase masing-masing $17.1 \%(\mathrm{n}=6)$.

\section{c. Pendidikan Ibu}

\begin{tabular}{|c|c|c|c|c|c|}
\hline \multicolumn{6}{|c|}{ Pendidikan Ibu } \\
\hline & & Frequency & Percent & $\begin{array}{c}\text { Valid } \\
\text { Percent }\end{array}$ & $\begin{array}{c}\text { Cumulative } \\
\text { Percent }\end{array}$ \\
\hline \multirow[t]{9}{*}{ Valid } & SD & 1 & 2.9 & 2.9 & 2.9 \\
\hline & $\overline{\text { SMP }}$ & 6 & 17.1 & 17.1 & 20.0 \\
\hline & $\overline{\text { SMA }}$ & 13 & 37.1 & 37.1 & 57.1 \\
\hline & $\overline{\text { SMK }}$ & 4 & 11.4 & 11.4 & 68.6 \\
\hline & $\overline{\mathrm{DI}}$ & 1 & 2.9 & 2.9 & 71.4 \\
\hline & $\overline{\text { DIII }}$ & 5 & 14.3 & 14.3 & 85.7 \\
\hline & $\overline{\text { DIV }}$ & 1 & 2.9 & 2.9 & 88.6 \\
\hline & $\mathrm{S} 1$ & 4 & 11.4 & 11.4 & 100.0 \\
\hline & $\overline{\text { Total }}$ & 35 & 100.0 & 100.0 & \\
\hline
\end{tabular}

Ditinjau dari pendidikan ibu, sebagian besar responden merupakan lulusan SMA sederajat yaitu sebesar $48.5 \%(n=17)$.

\section{d. Pemberian Kompres Hangat}

\begin{tabular}{|c|c|c|c|c|c|}
\hline \multicolumn{6}{|c|}{ Pemberian Kompres Hangat } \\
\hline & & $\begin{array}{l}\text { Freque- } \\
\text { ncy }\end{array}$ & Percent & $\begin{array}{l}\text { Valid } \\
\text { Percent }\end{array}$ & $\begin{array}{l}\text { Cumula- } \\
\text { tive } \\
\text { Percent }\end{array}$ \\
\hline \multirow[t]{3}{*}{ Valid } & Kurang & 17 & 48.6 & 48.6 & 48.6 \\
\hline & Baik & 18 & 51.4 & 51.4 & 100.0 \\
\hline & Total & 35 & 100.0 & 100.0 & \\
\hline
\end{tabular}

Sebagian besar responden sudah mengetahui pemberian kompres hangat lebih baik, yaitu sebanyak 51.4\%.

e. Motivasi Ibu

\begin{tabular}{cccccc}
\hline \multicolumn{4}{c}{ Motivasi } \\
\hline & $\begin{array}{c}\text { Freque- } \\
\text { ncy }\end{array}$ & Percent & $\begin{array}{c}\text { Valid } \\
\text { Percent }\end{array}$ & $\begin{array}{c}\text { Cumula- } \\
\text { tive } \\
\text { Percent }\end{array}$ \\
\hline Valid & Rendah & 15 & 42.9 & 42.9 & 42.9 \\
\cline { 2 - 6 } & Tinggi & 20 & 57.1 & 57.1 & 100.0 \\
\cline { 2 - 6 } & Total & 35 & 100.0 & 100.0 & \\
\hline
\end{tabular}

Lebih dari setengah total responden memiliki motivasi yang tinggi dalam pemberian kompres hangat, yaitu sebesar $57.1 \% \quad(n=20)$, sisanya masih memiliki motivasi yang cukup rendah.

\section{f. Pengetahuan Ibu}

\begin{tabular}{|c|c|c|c|c|c|}
\hline \multicolumn{6}{|c|}{ Pengetahuan } \\
\hline & & $\begin{array}{c}\text { Freque- } \\
\text { ncy }\end{array}$ & Percent & $\begin{array}{c}\text { Valid } \\
\text { Percent }\end{array}$ & $\begin{array}{c}\text { Cumulative } \\
\text { Percent }\end{array}$ \\
\hline \multirow[t]{4}{*}{ Valid } & kurang & 13 & 37.1 & 37.1 & 37.1 \\
\hline & cukup & 11 & 31.4 & 31.4 & 68.6 \\
\hline & baik & 11 & 31.4 & 31.4 & 100.0 \\
\hline & Total & 35 & 100.0 & 100.0 & \\
\hline
\end{tabular}

Dari seluruh responden, ibu yang memiliki pengetahuan baik dan cukup mengenai kompres hangat masing-masing berkisar $31.4 \%$. Sedangkan ibu yang berpengetahuan kurang masih cukup tinggi dibandingkan yang lain yaitu $37.1 \%$. 


\section{PEMBAHASAN}

\section{Analisis Bivariat}

a. Motivasi dengan Pemberian kompres hangat

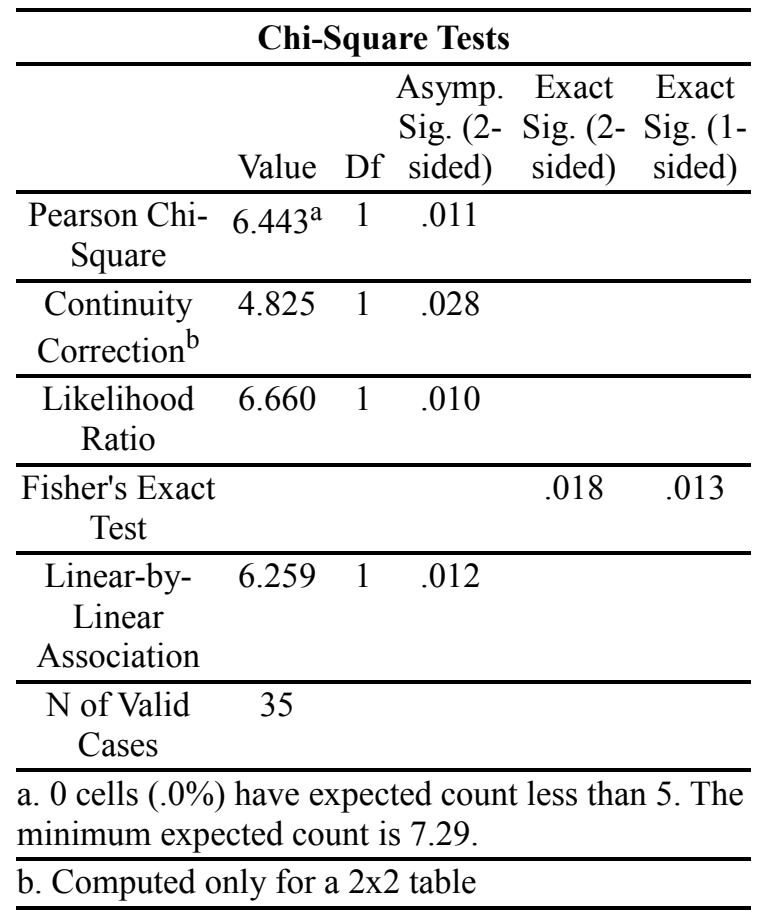

Pada tabel Chi Square Tests diperoleh nilai p-value (Asymp.Sig) sebesar 0.028.Karena nilai $\mathrm{P}$-value $0.028<0.05$, maka dapat disimpulkan bahwa hipotesis nol (H0) ditolak, artinya terdapat hubungan yang signifikan antara motivasi ibu dengan pemberian kompres hangat. Motivasi ibu memiliki korelasi dengan sikapnya dalam memberikan kompres hangat terhadap anak balitanya.

b. Pengetahuan dengan Pemberian kompres hangat

\begin{tabular}{cccc}
\hline \multicolumn{4}{c}{ Chi-Square Tests } \\
\hline & Value & Df & $\begin{array}{c}\text { Asymp. Sig. } \\
\text { (2-sided) }\end{array}$ \\
\hline Pearson Chi-Square & $15.180^{\mathrm{a}}$ & 2 & .001 \\
\hline Likelihood Ratio & 19.552 & 2 & .000 \\
\hline $\begin{array}{c}\text { Linear-by-Linear } \\
\text { Association }\end{array}$ & 10.495 & 1 & .001 \\
\hline N of Valid Cases & 35 \\
\hline $\begin{array}{c}\text { 0 cells (.0\%) have expected count less than 5. The } \\
\text { minimum expected count is 5.34. }\end{array}$ \\
\hline
\end{tabular}

\begin{tabular}{lccc}
\hline \multicolumn{4}{c}{ Chi-Square Tests } \\
\hline & Value & Df & $\begin{array}{c}\text { Asymp. Sig. } \\
\text { (2-sided) }\end{array}$ \\
\hline Pearson Chi-Square & $15.180^{\mathrm{a}}$ & 2 & .001 \\
\hline Likelihood Ratio & 19.552 & 2 & .000 \\
\hline $\begin{array}{c}\text { Linear-by-Linear } \\
\text { Association }\end{array}$ & 10.495 & 1 & .001 \\
\hline N of Valid Cases & 35 \\
\hline 0 cells (.0\%) have expected count less than 5. The \\
minimum expected count is 5.34. \\
\hline
\end{tabular}

\section{KESIMPULAN}

Berdasarkan hasil penelitian tentang hubungan pengetahuan ibu dengan pemberian kompres hangat pada balita febris di BPM Bidan Yetti Purnama, SST., M.Keb Kota Bengkulu dapat disimpulkan:

1. Terdapat hubungan yang signifikan antara pengetahuan ibu dengan pemberian kompres hangat. Dimana nilai P-value $0.01<0.05$.

2. Terdapat hubungan yang signifikan antara Motivasi ibu dengan pemberian kompres hangat. Dimana nilai P-value $0.028<0.05$.

\section{SARAN}

Kepada peneliti selanjutnya diharapkan agar berupaya lebih mengembangkan dan memperdalam bahasan tentang Hubungan Pengetahuan Dan Motivasi Ibu Dengan Pemberian Kompres Hangat Pada Balita Febris dengan menggunakan desain penelitian yang lain.

\section{DAFTAR PUSTAKA}

Arikunto. 2009. Prosedur Penelitian. Jakarta: Rineka Cipta.

Bandiyah.2013. Keterampilan Dasar dalam Keperawatan (KDK).Yogyakarta: Nuha Medika.

Corwin. 2006. Buku Saku Patofisiologi. Jakarta: EGC

Damayanti. 2008. Hubungan Tingkat pengetahuan tentang Demam dengan 
Perilaku Kompres Di Ruang Rawat Inap RSUD Dr. Moewardi Surakarta. Diakses dari

http://eprints.ums.ac.id/1879/1/J210040 011.pdf tanggal 20 November 2015.

Gloria \& Kuklierus. 2008. Buku Ketika Sikecil Sakit. Jakarta: Salemba Medika

Latifah. 2012. Pengantar Psikologi Pendidikan. Yogyakarta: Pedagogia.

Nur Hadi. 2012. Perbedaan Efektifitas Pemberian Kompres Hangat dan Kompres Air Biasa pada Daerah Axillaris terhadap Penurunan Suhu Tubuh pada Pasien FebrisdiUPT Puskesmas Mantup Lamongan.Diakses darihttp://skripsienjoy.blogspot.co.id/p/blog-page.html tanggal 27 November 2015.

Notoatmodjo, S. 2010. Promosi Kesehatan Teori \& Aplikasi. Jakarta: Rineka Cipta

, S. 2012. Metodologi Penelitian Kesehatan. Jakarta : Rineka Cipta

Nurarif \& Kusuma.2013. Aplikasi Asuhan Keperawatan berdasarkan Diagnosa Medis \& Nanda Jilid 1. Yogyakarta: Mediaction Publishing.

Nurjannah. 2012. Faktor yang Berhubungan dengan Lama Hari Rawat Inap Pasien Demam Tifoid Di Ruang Inap RSUD Rangkep.

Profil Dinas Kesehatan Kota Bengkulu. 2015. Profil Kesehatan Kota Bengkulu tahun 2014. Bengkulu.

Rahmawati. 2008. Hubungan Antara Tingkat Pengetahuan Dengan Sikap Ibu MenghadapiDemam Pada Anak Balita Di Desa Ngembat Padas Kecamatan GemolongKabupaten Sragen. Naskah dipublikasikan

Ranuh. 2012. Tumbuh Kembang Anak. Jakarta: EGC.

Riyanto. 2009. Pengolahan dan Analisis Data Kesehatan. Yogyakarta: Nuha Medika.

Riandita. 2012. Hubungan antara Tingkat Pengetahuan Ibutentang Demam dengan Pengelolaan Demampada Anak.Naskah dipublikasikan

Setiadi. 2007. Konsep \& Penulisan Riset Keperawatan. Jakarta: Graha Ilmu.
Soemanto. 2009. Psikologi Pendidikan. Jakarta : PT Rineka Cipta

Sugiarti.2012. Hubungan Motivasi dan Pengetahuan Ibu dengan Pemberian Kompres Hangat pada Anak Demam Thypoid di Wilayah Kerja Puskesmas Anggut Atas Kota Bengkulu.Skripsi tidak Dipublikasikan.

Valman. 2007. Diagram Penyakit Anak dan Cara Mengatasinya.Yogyakarta : Citra Pustaka.

Wawan \& Dewi, 2011.Teori \& Pengukuran Pengetahuaan, Sikap, dan Prilaku Manusia.Yogyakarta: Nuha Medika

Widyawati. 2012. Konsep Dasar Keperawatan. Jakarta: Prestasi Pustakaraya

Willis. 2012. Psikologi Pendidikan. Bandung: Alfabeta. 